logos_i_ethos_2013_1_(34), s. 109-127

\title{
Igor Nowikow
}

\section{Rodzina jako fundament kształtowania człowieka. Szkic do Metafizyki macierzyństwa Wilhelma Schappa}

W epilogu swego ostatniego dzieła Bracia Karamazow z roku 1880 Teodor M. Dostojewski podejmuje temat wychowania. Jedna z głównych postaci powieści, Aleksy Karamazow, wypowiada nad grobem zmarłego chłopca, Iljuszy, następujące słowa:

Wiedzcie, że nie ma nic lepszego, silniejszego, zdrowszego i pożyteczniejszego dla życia nad jakieś dobre wspomnienie, zwłaszcza wyniesione $\mathrm{z}$ dzieciństwa, $\mathrm{z}$ domu rodzicielskiego. Dużo wam się prawi o waszym wychowaniu, ale przecież piękne, święte wspomnienie, zachowane z dzieciństwa, jest zarazem najlepszym wychowaniem. Jeżeli wiele się nazbiera takich wspomnień, to człowiek jest zbawiony na całe życie. I jeżeli nawet bodaj jedno dobre wspomnienie zostanie w waszym sercu, to i ono może przyczynić się do waszego zbawienia ${ }^{1}$.
Igor Nowikow ukończył z wyróżnieniem studia germanistyczno-filozoficzne na Uniwersytecie Justusa Liebiga w Giessen (Niemcy). Od roku 2009, jako stypendysta Instytutu Filozofii na Uniwersytecie im. Adama Mickiewicza w Poznaniu, pracuje nad rozprawą doktorską Der Freiheitsbegriff bei Kant. Eine philosophische Untersuchung im Rückblick auf das christliche Freiheitsverständnis. Współpracował $w$ charakterze tłumacza $\mathrm{z}$ redakcją pisma „Praca nad sobą"; prowadził zajęcia w szkołach wyższych w Poznaniu, Łodzi i Piotrkowie Trybunalskim. Zainteresowania autora dotyczą przede wszystkim niemieckiej filozofii praktycznej, etyki i filozofii chrześcijańskiej. Tradycja, do której nawiązuje w swoich badaniach, to twórczość filozoficzna Jana Schappa oraz Wilhelma Schappa.

Dostojewski ukończył swą powieść w listopadzie 1880 roku, dwa miesiące przed śmiercią, i dlatego można przypuszczać, że mamy tutaj do czynienia $\mathrm{z}$ jedną $\mathrm{z}$ ostatnich udokumentowanych opinii pisarza na temat pamięci, rodziny i wychowania. Dla osób zaznajomionych 
z twórczością Dostojewskiego nie będzie zaskoczeniem fakt, że ustami Aleksego Karamazowa przemawia najprawdopodobniej sam autor ${ }^{2}$.

To, że Dostojewski nadaje tak wielkie znaczenie domowi rodzinnemu, może zachęcić kogoś zainteresowanego filozofią Zachodu do postawienia pytania, czy pośród bogatych jej zasobów można napotkać tekst, który w podobnie zdecydowany sposób doceniłby rolę domu rodzinnego i którego myśli podążałyby w kierunku nakreślonym przez Dostojewskiego. W związku z tym pytaniem chciałbym wskazać na traktat niemieckiego filozofa Wilhelma Schappa Zur Metaphysik des Muttertums ${ }^{3}$. Książka ta została napisana w roku 1937, jednakże ukazała się dopiero w roku 1965, czternaście dni przed śmiercią autora ${ }^{4}$. Nie istnieje polski przekład tego dzieła; w niniejszym szkicu proponuję tytuł Metafizyka macierzyństwa, którym będę się dalej posługiwał ${ }^{5}$. Jeśli chodzi o tradycję filozoficzną, z której wywodzi się myśl W. Schappa, to był on uczniem twórcy fenomenologii, Edmunda Husserla. Jan Schapp, syn Wilhelma, charakteryzuje Metafizykę macierzyństwa jako jedną z części powstałej w latach trzydziestych XX wieku trylogii fenomenologicznej swego ojca, trylogii, która podejmuje temat wartości. Zwraca on zarazem uwagę na osobliwą pozycję Metafizyki macierzyństwa w tejże trylogii oraz na to, że tematy w niej poruszone zostały później podjęte przez W. Schappa w jego filozofii historii z lat pięćdziesiątych i sześćdziesiątych ${ }^{6}$.

Por. tenże, Dziennik pisarza, tłum. M. Leśniewska, t. 2, Warszawa 1982, s. 75, 348.

W. Schapp, Zur Metaphysik des Muttertums, Den Haag 1965.

O tych szczegółach poinformował mnie Jan Schapp.

5 Trudno było mi znaleźć lepszy przekład słowa Muttertum niż polskie słowo „macierzyństwo". W języku niemieckim występują dwa słowa: powszechnie używane Mutterschaft oraz niezwykle rzadkie Muttertum. Jan Schapp zwrócił mi uwagę na to, że słowa te różnią się znaczeniowo, choć różnica ta jest niezwykle trudna do uchwycenia. Jego zdaniem słowo Mutterschaft oznacza „daną obiektywną", opisaną „od zewnątrz”, natomiast słowo Muttertum onacza „stosunek matki do dziecka z punktu widzenia matki”. Poza tym słowo Muttertum wyraża, według Jana Schappa, coś substancjalnego, podczas gdy słowo Mutterschaft nie budzi takich skojarzeń.

${ }^{6} \quad$ Por. J. Schapp, Geschichtenphilosophie und Recht, [w:] Das Denken Wilhelm Schapps. Perspektiven für unsere Zeit, Hrsg. K. Joisten, Freiburg im Br. 2010, s. 65n, 81n. Poza Zur Metaphysik des Muttertums do trylogii fenomenologicznej należy dwutomowe dzieło Die neue Wissenschaft vom Recht, tom pierwszy: Der Vertrag als Vorgegebenheit, tom drugi: Wert, Werk und Eigentum (Berlin-Grunewald 1930 i 1932). Do trylogii filozoficzno-historycznej należą: In Geschichten 
Głównym tematem Metafizyki macierzyństwa jest miłość pomiędzy matką a dzieckiem; problematyka wychowania dochodzi do głosu właśnie $\mathrm{w}$ tym zasadniczym kontekście. W ten sposób na plan pierwszy rozważań wysuwa się rodzina, będąca naturalnym środowiskiem wychowania. Jednocześnie W. Schapp nie obawia się zdecydowanego nawiązania do religii chrześcijańskiej. Jan Schapp, charakteryzując traktat swego ojca, zauważa, że jego ostateczną warstwę tematyczną stanowią związki zachodzące pomiędzy rodziną a religią chrześcijańską, i że fakt ten usprawiedliwia zastosowanie w tytule traktatu słowa "metafizyka". Jednocześnie zwraca on uwagę na to, że w przypadku W. Schappa - w odróżnieniu od myśli Arystotelesa, Althusiusa czy Hegla - metafizyka w takim właśnie rozumieniu zdaje się pojawiać w miejsce filozofii państwa ${ }^{7}$. Taka interpretacja wydaje się być zgodna z tekstem W. Schappa, a jest ona o tyle istotna, że wskazuje na prymat rodziny i religii przed strukturami państwowymi.

W niniejszym szkicu chciałbym zbadać traktat Metafizyka macierzyństwa pod kątem problematyki wychowania. Zadanie to wydaje mi się jednak prawie niemożliwe do wykonania bez wcześniejszego zbadania zasadniczych elementów myśli autora, zawartych w tym traktacie. Dlatego uważam za stosowne podzielić niniejszy szkic na dwie części: w części pierwszej, wprowadzającej, zajmę się zbadaniem znaczenia tytułowego wyrażenia „metafizyka macierzyństwa”, a dopiero w drugiej, zasadniczej części pracy, zajmę się problematyką rodziny i wychowania. W obydwu tych częściach będę się starał dokonać interpretacji myśli W. Schappa. Natomiast w trzeciej, ostatniej części, zajmę się kilkoma wybranymi problemami, przed którymi może stanąć współczesny czytelnik w związku z omawianą książką. W części tej zasygnalizuję również związki, zachodzące pomiędzy rodziną, by wskazać na duchową ojczyznę myśli W. Schappa oraz żeby zbudować pomost, łączący jego myśl z przytoczonymi na wstępie słowami Dostojewskiego. 


\section{Metafizyka macierzyństwa}

W pierwszych zdaniach Metafizyki macierzyństwa W. Schapp zauważa, że rodzaj ludzki zawsze należycie doceniał znaczenie rodziny i pokrewieństwa. Jednocześnie największe zainteresowanie wzbudzało nie tyle samo pokrewieństwo, ile raczej rodzina. W. Schapp proponuje odwrotny sposób postępowania: w centrum zainteresowania stawia on pokrewieństwo, mając przy tym nadzieję, że rozjaśniając problematykę pokrewieństwa, rzuci nieco światła na rodzinę. Autor zwraca dalej uwagę na różne rodzaje pokrewieństwa ludzkiego (matka - dziecko, ojciec - dziecko, rodzeństwo, dziadkowie -dziecko), przy czym charakteryzuje on relację matka - dziecko i, „być może”, ojciec - dziecko, jako tę, w której napotykamy na „najgłębszy i najbardziej wewnętrzny sens pojęcia pokrewieństwo" ${ }^{9}$. Ostrożne sformułowanie, przejawiające się zastosowaniem wyrażenia modalnego „być może”, wynika z tego, że W. Schapp w dalszych partiach tekstu scharakteryzuje ojcostwo jako pokrewieństwo, które powstaje dopiero za sprawą macierzyństwa ${ }^{10}$, a jeszcze później stwierdzi, że również wszelkie inne rodzaje pokrewieństwa są pochodnymi pokrewieństwa matka - dziecko ${ }^{11}$.

Relację matka - dziecko W. Schapp charakteryzuje jako relację duchową, a nie biologiczną. Jej istotą jest miłość: matka zwraca się z miłością do swego dziecka, a dziecko odpowiada na miłość matki jak „żywe echo"12. Według W. Schappa relacja ta nigdy nie może zostać wyjaśniona biologią; biologiczne procesy, takie jak zajście w ciążę czy narodziny, nie przyczyniają się w żadnej mierze do powstania duchowego pokrewieństwa. Trudno pomyśleć sobie tutaj jakiś związek semantyczny, czy też związek przyczynowo-skutkowy ${ }^{13}$. Dlatego też kobieta, będąca matką jedynie w sensie biologicznym, nie jest według W. Schappa eo

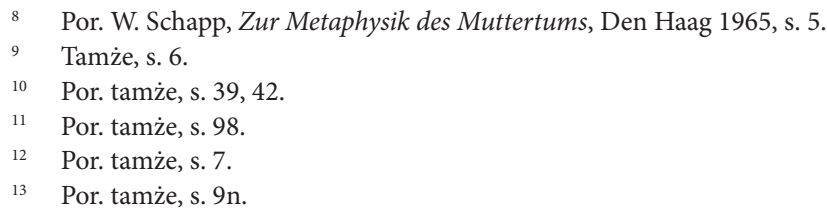


ipso matką w prawdziwym sensie tego słowa ${ }^{14}$. Autor zwraca w tym kontekście uwagę, że chociaż wiedza biologiczna ulegała w historii ciągłym przekształceniom, to jednak fakt ten nie miał najmniejszego wpływu na duchową relację matka - dziecko ${ }^{15}$. W. Schapp charakteryzuje tę relację jako zawsze i wszędzie taką samą ${ }^{16}$. Zauważa też, że w życiu pojedynczej kobiety macierzyństwo nie rozpoczyna się dopiero w momencie urodzenia dziecka, a nawet nie w momencie zajścia w ciążę, lecz znacznie wcześniej, „wraz z pierwszą zabawą lalkami”"

Tytułowe pojęcie „macierzyństwo” (Muttertum) pojawia się już w pierwszym rozdziale traktatu ${ }^{18}$; z kontekstu można wywnioskować, że jest ono tutaj synonimem wyrażenia „relacja matka - dziecko”. Takie użycie tego pojęcia pojawia się w tekście jeszcze wielokrotnie; można je określić jako użycie podstawowe. W traktacie pojawiają się również fragmenty, w których słowo „macierzyństwo” uzyskuje znacznie szersze znaczenie:

Siła i znaczenie macierzyństwa są dla nas tak duże, że w naszych oczach miałoby sens mówienie o macierzyństwie nawet bez człowieczeństwa, bez humanizmu, bez praczłowieczeństwa, natomiast nie miałoby żadnego sensu mówienie o człowieczeństwie bez macierzyństwa. Warunkiem wszystkich kultur i cywilizacji jest macierzyństwo, wszystkie one wznoszą swój gmach właśnie na nim, są jego tworem; natomiast samo macierzyństwo zachowałoby swoją najgłębszą i ostateczną treść również bez tych wszystkich kultur i cywilizacji. Tendencją macierzyństwa jest przeniknięcie całego człowieczeństwa. Może się ono jednak rozwijać również w najwęższym kręgu, w ramach relacji matka - dziecko ${ }^{19}$.

A zatem macierzyństwo to nie tylko stosunek matka - dziecko, choćby nawet w sensie metafizycznym, lecz również wielka metafizyczna siła,

14 Wilhelm Schapp krytykuje takie użycie języka, w którym na oznaczenie matki biologicznej (Gebärerin) używa się słowa „matka”. Por. tamże, s. 17n.

15 Por. tamże, s. 9.

16 Por. tamże, s. 8.

17 Tamże, s. 11.

18 Tamże, s. 9.

19 Tamże, s. 25n. 
utrzymująca ludzkość w istnieniu. W tym ostatnim, najszerszym sensie, macierzyństwo to siła będąca warunkiem wszelkiej kultury i cywilizacji, a nawet ludzkości jako takiej. Tym samym macierzyństwu przypisany zostaje tutaj niemalże boski charakter.

W swych rozważaniach W. Schapp jest zainteresowany przede wszystkim metafizyczną stroną macierzyństwa. Termin „metafizyka” ma swoją długą historię w zachodniej filozofii - wystarczy wspomnieć choćby Arystotelesa, św. Tomasza z Akwinu czy Kanta. W. Schapp używa pojęcia „metafizyka” w kontekście macierzyństwa, to znaczy - ujmując rzecz matematycznie - przedmiotem jego zainteresowania jest część wspólna dwóch wielkich obszarów: obszaru metafizyki i obszaru macierzyństwa. Samo słowo „metafizyka”, poza tytułem traktatu, trudno jednak w tekście napotkać; pojawia się natomiast jego przymiotnikowa forma, na przykład w zwrocie „metafizyczne ja” ${ }^{20}$. W kontekście metafizyki należy też zwrócić uwagę na to, że W. Schapp rozróżnia substancję i zjawisko (ewentualnie: obraz zjawiska) ${ }^{21}$. Zamiast słowa „substancja” autor używa jednak dużo chętniej choćby takiego wyrażenia, jak „ostateczne głębie duchowe” (letzte seelische Tiefen), będące podstawą wszelkich zjawisk:

W przypadku macierzyństwa mamy pewność, że towarzyszącym mu zjawiskom odpowiadają ostateczne głębie duchowe, ostateczne duchowe źródła, z których zjawiska te wyłaniają się spontanicznie i ciągle od nowa ${ }^{22}$.

Ponadto autor używa w tym kontekście również takich zwrotów, jak „duchowy” (seelisch), „duchowa struktura” (seelische Struktur) czy „duchowa treść" (seelischer Gehalt) ${ }^{23}$. Zwraca uwagę fakt, że nie padają tu takie słowa, jak Geist czy geistig, które w języku niemieckim są odpowiednikami polskich słów „duch” i „duchowy”. W. Schapp używa utworzonego

\footnotetext{
20 Tamże, s. 112.

21 Por. tamże, s. 36n.

22 Tamże, s. 37.

23 Tamże, s. 40.
} 
od słowa Seele (dusza) wyrazu seelisch, które w sensie dosłownym musiałoby być przetłumaczone na język polski jako „duszny” ${ }^{24}$.

Wydaje się, że znaczenie słowa „metafizyka” u W. Schappa najlepiej wyrażone jest w sformułowaniu „ostateczne głębie duchowe”. Wyrażenie „metafizyka macierzyństwa” należałoby zatem rozumieć jako „ostateczne głębie duchowe macierzyństwa". Głębie te dają się wprawdzie odczytać jedynie ze zjawisk, ale nie są one z nimi tożsame. Ich istotą jest miłość macierzyńska i dlatego wyrażenie „metafizyka macierzyństwa” oznacza po prostu miłość macierzyńską. W filozofii W. Schappa królestwo metafizyki nie jest królestwem rozumu, lecz królestwem miłości. Rozum jest wprawdzie zdolny, aby rzucić nieco światła na to, czym jest macierzyństwo, nie może on jednak w żaden sposób do końca go objaśnić, ponieważ nie można objaśnić miłości rozumem. $Z$ tego również względu rozum nie może zastąpić miłości macierzyńskiej. Na ograniczoną rolę rozumu w tych sprawach W. Schapp zwraca uwagę w ostatnich słowach swego dzieła ${ }^{25}$.

\section{Rodzina i wychowanie}

W traktacie Metafizyka macierzyństwa W. Schapp nie prezentuje jakiejś gotowej teorii wychowania. W sposób bezpośredni autor mówi o wychowaniu zaledwie kilka razy ${ }^{26}$, jednak ze względu na to, że tematem traktatu jest rodzina, problematyka wychowania jest w nim stale obecna. Metodę W. Schappa można by scharakteryzować jako prostą, niezmąconą przed-sądami obserwację. Wykorzystuje on liczne przykłady z życia empirycznego, historii i literatury, zwłaszcza literatury antycznej (Homer). Język autora, nawiązujący do niemieckiej tradycji filozoficznej, jest zarazem bardzo klarowny i żywy, czasem pojawiają się

24 Ze względów językowych tłumaczę słowo seelisch jako „duchowy”, a nie „duszny”. Polskie słowo „psychiczny” też nie wydaje mi się najlepszym tłumaczeniem w kontekście traktatu Wilhelma Schappa. Inny fenomenolog, Max Scheler, rozróżnia natomiast bardzo wyraźnie pomiędzy duszą (Seele) a duchem (Geist). Por. M. Scheler, Die Stellung des Menschen im Kosmos, Bonn 2002, s. 38 .

25 Por. W. Schapp, Zur Metaphysik..., dz. cyt., s. 168.

26 Por. tamże, s. 70n, 102n, 117n. 
wręcz literackie fragmenty (w pozytywnym sensie tego słowa ${ }^{27}$. Z traktatu można się dowiedzieć o wielu interesujących faktach $z$ historii moralności i prawa; W. Schapp był prawnikiem, a jego dzieło miało być w pierwotnym zamyśle traktatem na temat prawa rodzinnego. Wielką zaletą książki jest wskazanie na tradycję, będącą istotnym elementem wychowania. Perspektywa historyczna obejmuje tutaj wiele tysiącleci, przy czym autor podkreśla historyczną ciągłość rozwoju rodziny.

W swej pracy W. Schapp wskazuje na rodzinę jako na miejsce wychowania. Kluczową sprawą staje się zatem zrozumienie tego, czym jest rodzina, a według autora możliwe jest to wówczas, kiedy zrozumiemy, czym jest macierzyństwo oraz kiedy porównamy macierzyństwo z ojcostwem. Dopiero na tak zarysowanym tle problematyka wychowania może nabrać wyraźniejszych konturów.

Zasadniczą tezą traktatu W. Schappa jest teza o prymacie macierzyństwa przed ojcostwem. W perspektywie historycznej autor postrzega macierzyństwo jako coś, co istniało we wszystkich kulturach i we wszystkich czasach, zachowując przy tym ten sam sens ${ }^{28}$. Natomiast rozważania autora na temat ojcostwa odnoszą się wyłącznie do ojcostwa w sensie zachodnim. Ojcostwo w tym sensie, a z nim również i zachodnia rodzina, ukształtowało się, zdaniem W. Schappa, przed około trzema tysiącami lat, przy czym czas przygotowujący to zdarzenie obejmował „wiele tysiącleci wcześniej”. Od tego czasu zmienił się, co prawda, zewnętrzny obraz rodziny, ale nie jej istota ${ }^{29}$. Te historyczne związki są wprawdzie zdaniem autora istotne, ale najważniejszy jest metafizyczny aspekt problemu. W. Schapp uważa, że mężczyzna nie staje się ojcem ze względu na biologiczne ojcostwo czy wolę bycia ojcem, lecz zostaje nim dopiero z przyzwolenia matki. Autor wyraża tę myśl w centralnym zdaniu: „Matka jest tą osobą, która podprowadza dziecko do ojca w sensie duchowym" ${ }^{30}$. Macierzyństwo jest czymś niezależnym od ojcostwa, natomiast ojcostwo jest zależne od

\footnotetext{
27 Por. tamże, s. 48.

28 Por. tamże, s. 8, zwłaszcza zaś s. 25.

29 Por. tamże, s. 27, zwłaszcza s. 33n.

30 Tamże, s. 41.
} 
macierzyństwa: „Pełne ojcostwo zakłada wspólnotę pomiędzy matką a ojcem. Pełne macierzyństwo jest od tej wspólnoty niezależne" ${ }^{31}$. A zatem do tego, aby mężczyzna stał się ojcem, nie wystarcza jego subiektywna wola, lecz potrzebuje on przyzwolenia matki. W tym sensie to właśnie matka ma de facto nieograniczoną władzę nad mężczyzną ${ }^{32}$. Prymat macierzyństwa W. Schapp ilustruje za pomocą przykładu nieślubnego dziecka: w prawodawstwie zachodnim ojciec nieślubnego dziecka nie ma do niego praktycznie żadnych praw, prawo takie posiada jedynie matka. Ten stan prawny jest, według autora, odbiciem naturalnego stanu rzeczy: prymatu macierzyństwa przed ojcostwem; prawo jest tutaj jedynie czymś wtórnym wobec rzeczywistości ${ }^{33}$.

Macierzyństwo i ojcostwo nie są zatem dla W. Schappa czymś równym; nie są one nawet czymś podobnym. Jako różne metafizyczne wielkości tworzą one jednak pewną metafizyczną jedność: rodzinę w sensie zachodnim.

Argumenty W. Schappa na rzecz pierwszeństwa macierzyństwa (być może słowo „argument” nie jest tu najszczęśliwsze, ponieważ wskazuje ono na określony styl filozofowania, niebędący stylem autora) zaczerpnięte są przede wszystkim ze sfery empirycznej; nie są to argumenty pochodzące ze spekulacji rozumowej ${ }^{34}$. Autor używa w tym kontekście takich określeń, jak: „natura” (Natur) ${ }^{35}$, „istota” (Wesen), „substancja” (Substanz), „pierwotna siła” (Urgewalt) ${ }^{36}$, „pierwotne prawa” (Urgesetze), „pierwotne skłonności” (Urrichtungen) ${ }^{37}$. Wszystkie te pojęcia wyrażają myśl, że istnieje coś pierwotnego względem kultury, coś, co umożliwia kulturę jako taką. Warto zwrócić szczególną uwagę na pojęcie natury, ponieważ współcześnie zostało ono zaanektowane przez

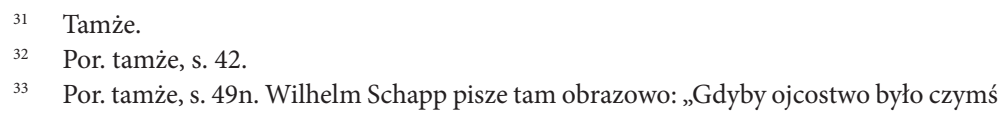
podobnym do macierzyństwa, to wtedy ani władza kościelna, ani władza państwowa, ani piekło, ani niebo nie mogłyby rozdzielić ojca od dziecka“.

34 Por. tamże, s. 45n, 49, 52.

35 Por. tamże, s. 48.

36 Por. tamże, s. 49, 53.

37 Por. tamże, s. 54. 
nauki przyrodnicze. Tymczasem W. Schapp mówi o naturze ludzkiej nie $\mathrm{w}$ sensie przyrodniczym, lecz w sensie metafizycznym ${ }^{38}$. Założenie istnienia tak rozumianej natury ludzkiej ma z kolei istotne konsekwencje dla problematyki wychowania, ponieważ w ten sposób można wyraźniej określić cele wychowawcze oraz uniknąć pewnej dowolności. Mając na uwadze fakt, że u omawianego tu autora natury ojcostwa i macierzyństwa nie są takie same, można się spodziewać, że w procesie wychowania role ojca i matki będą zupełnie różne.

Pojęcie wychowania, pojawiające się w tekście W. Schappa lub ewentualnie z niego wynikające, można by scharakteryzować najogólniej $\mathrm{w}$ ten sposób, że oznacza ono wprowadzenie człowieka w życie. Autor zwraca uwage przede wszystkim na rodzicielski aspekt tak rozumianego wychowania. Wychowawcami wprowadzającymi w życie są tutaj rodzice, a wychowankami - dzieci. Proces wychowawczy przypada zasadniczo na czas dzieciństwa i młodości; natomiast macierzyństwo i ojcostwo trwają, według autora, przez całe życie matki i ojca. Ze swej strony dzieci również odgrywają ważną rolę w życiu swych rodziców. Stanowią one mianowicie przedłużenie życia ziemskiego rodziców i dlatego można je postrzegać jako odpowiednik idei nieśmiertelności duszy. Chodzi tu zatem o ziemską nieśmiertelność uzyskiwaną poprzez dzieci ${ }^{39}$.

Jeśli chodzi o rolę matki w procesie wychowania, to stanowi ona metafizyczne centrum rodziny. Warto przytoczyć w tym miejscu słowa samego autora:

Kobieta ogarnia swoim macierzyństwem również i mężczyznę. Mało tego: macierzyństwo promieniuje na całe otoczenie kobiety, tworzy centrum, podobnie jak ogień w kuchni, który płonie zupełnie innym blaskiem, promieniuje zupełnie innym

38 Pojęcie natury człowieka pojawia się dziś przede wszystkim w obrębie myśli tomistycznej, ale czasami można je napotkać również u innych autorów; jest ono na przykład ważnym elementem libertariańskiej filozofii Murraya N. Rothbarda. Por. M. N. Rothbard, Etyka wolności [1982], tłum. J. Woziński, J. M. Fijor, Warszawa 2010, s. 73n.

39 Por. W. Schapp, Zur Metaphysik..., dz. cyt., s. 68n. Jeśli chodzi o temat nieśmiertelności rodziców poprzez dzieci por. dramat Strindberga Ojciec. Wyd. niem.: A. Strindberg, Der Vater [1887], Stuttgart 1990, s. 46. 
ciepłem, kiedy jest doglądany przez kobietę. Z macierzyństwa wyłania się melodia, dźwięk i blask, oddziałujące na cały dom, na wszystko, co w domu przebywa, na rodzinę i służbę, na gości i obcych, na zwierzęta w domu, psa i kota, na wszystkie zwierzęta w obejściu, na rośliny i kwiaty. Wszystko, co zdrowe i silne, cieszy się z opieki kobiety; wszystko, co chore i bezbronne, odczuwa ulgę wraz z jej nadejściem. Martwy, zimny i pusty jest dom i obejście, gdy zabraknie matki ${ }^{40}$.

Taki sposób pisania występuje niezwykle rzadko we współczesnych tekstach filozoficznych. Za pomocą prostego opisu autorowi udaje się ująć istotę problemu, podczas gdy abstrakcyjny styl filozofii nie byłby prawdopodobnie do tego w ogóle zdolny. Nie jest zapewne przypadkiem fakt, że W. Schapp w swej książce wielokroć odwołuje się do przeróżnych tekstów literackich ${ }^{41}$. Warto przypomnieć w tym kontekście słowa Dostojewskiego, który zwrócił uwagę na to, że dobra, pouczająca historia jest znacznie lepszym środkiem wychowawczym niż abstrakcyjna doktryna ${ }^{42}$. Opowiedziana historia posługuje się w głównej mierze postrzeżeniami, a nie abstrakcyjnymi pojęciami. Jako fenomenolog, W. Schapp nadaje szczególną wartość umiejętności postrzegania, będącej przeciwieństwem czysto intelektualnej konstrukcji ${ }^{43}$. W tym sensie jest on kontynuatorem wielkiej filozoficznej tradycji, związanej z takimi choćby postaciami, jak Platon czy Goethe. Platońska idea dobra i Goethowska idea rośliny nie są ideami abstrakcyjnymi, lecz ideami postrzeganymi duchem.

Macierzyństwo stanowi zatem fundament rodziny i wychowania w tym sensie, że matka tworzy metafizyczne centrum rodziny, promieniujące miłością na pozostałych jej członków. Jeśli zabraknie takiej miłości, trudno mówić o rodzinie:

40 W. Schapp, Zur Metaphysik..., dz. cyt., s. 48.

${ }_{41}$ Por. tamże; W. Schapp nawiązuje do Homera (s. 28n, 56n), Goethego (s. 43, 113, 118), Schillera (s. 155), braci Grimm (s. 104), Dickensa (s. 132).

42 Por. F. Dostojewski, Dziennik pisarza, t. 2, dz. cyt., s. 26n.

43 Por. uwagi Jana Schappa o istocie fenomenologii w: J. Schapp, Phänomenologie und Christentum, [w:] Gießener Hochschulgespräche und Hochschulpredigten der ESG, VIII/SS 05, s. 51n, zwłaszcza s. 53n. Jan Schapp zwraca tam uwagę na stwierdzenie Husserla, że fenomenologia objaśnia metodą postrzegania i że nie daje ona wyjaśnień w sensie jakiejś dedukcyjnej teorii. 
Tam, gdzie miłość ta jest obecna, gdzie promienie miłości świecą pełnym blaskiem, tam można mówić o rodzinie i pokrewieństwie we właściwym tych słów znaczeniu. Jeśli jednak zabraknie tej miłości, to właściwie nie może być już mowy ani o rodzinie, ani o pokrewieństwie ${ }^{44}$.

Promieniowanie miłości nie ogranicza się jednak do samej rodziny, lecz swym zasięgiem obejmuje pośrednio także dalszych krewnych, większe wspólnoty, a nawet całe narody ${ }^{45}$.

Na fundamencie miłości matka wprowadza swe dzieci w przeróżne obszary życia, między innymi w świat etyki. Wilhelm Schapp mówi w tym kontekście o tradycyjnym porządku (überkommene Ordnungen) ${ }^{46}$. Wprowadzenie to jest skierowane zarówno do synów, jak i do córek, przy czym jedynie córki, jako przyszłe matki, są odpowiedzialne za dalsze przekazanie tego porządku swym dzieciom. W. Schapp sądzi, że w życiu człowieka może dojść do poważnych zaburzeń, jeśli zabraknie matki przekazującej tradycyjny porządek etyczny i jakieś mniej powołane osoby czy też instytucje będą próbowały ją w tej roli zastąpić. Autor zwraca uwagę, że rola matki jest tutaj podobna do roli, jaką odgrywa kształcenie instytucjonalne, na przykład prawnicze, choć różnica polega na tym, że w swoim wprowadzeniu matka wykorzystuje przede wszystkim osobiste doświadczenie. Poza etyką, matka wprowadza swe dzieci również w świat religii. W filozofii W. Schappa trzy obszary: religia, etyka oraz prawo wydają się być ściśle ze sobą powiązane ${ }^{47}$.

Matka jest zatem de facto pierwszą przekazicielką religijnej, etycznej i prawnej tradycji. W jednej ze swych późniejszych prac, w wydanej w roku 1953 książce In Geschichten verstrickt. Zum Sein von Mensch und Ding, W. Schapp, kontynuując ten wątek, napisał: „Świat pogrążyłby się w całkowitym chaosie i anarchii, jeśliby chociaż przez

44 Por. W. Schapp, Zur Metaphysik..., dz. cyt., s. 135.

45 Por. tamże, s. 135n.

46 Por. tamże, s. 105n. W tym kontekście pada też sformułowanie „kręgi normatywne” (Normenkreise).

47 Również Jan Schapp szuka w swej filozofii prawa związków pomiędzy tymi trzema sferami. Por. J. Schapp, Freiheit, Moral und Recht, Tübingen 1994. 
jeden dzień zabrakło tego, co zawarte jest w tej relacji [relacji matka - dziecko - I. N.]" ${ }^{\prime 4}$.

$\mathrm{Z}$ uwagi na fakt, że bez macierzyństwa nie byłoby ojcostwa w prawdziwym sensie tego słowa, rola ojcostwa $\mathrm{w}$ procesie wychowania staje się zrozumiała jedynie w kontekście macierzyństwa. Chociaż w filozofii W. Schappa to matka wydaje się być tą osobą, która odgrywa najistotniejszą rolę w procesie domowego wychowania, to jednak autor porusza również kilka aspektów, które pozwalają lepiej zrozumieć rolę ojca w wychowaniu dzieci. Po pierwsze, zwraca on uwagę na to, że dzisiejsze wychowanie instytucjonalne nie zawsze istniało, i że niegdyś - autor ma na myśli czasy Homera - zadaniem ojca było wprowadzenie syna w krąg kultury i cywilizacji ${ }^{49}$. Po drugie, W. Schapp analizuje relacje pomiędzy ojcostwem a własnością.

Pojęcie własności odgrywa niezwykle istotną rolę w myśleniu nowożytnym, przy czym $\mathrm{w}$ centrum zainteresowania stoi problem własności prywatnej. W tej kwestii dają się zauważyć dwa przeciwstawne punkty widzenia: jedni opowiadają się zdecydowanie za własnością prywatną (tradycja wywodząca się od Locke’a), inni są jej przeciwnikami (tradycja wywodząca się od Marksa). W sporze tym W. Schapp reprezentuje zasadniczo stanowisko prowłasnościowe. Pochwale własności prywatnej towarzyszy jednak pewne zastrzeżenie: własność nie powinna być postrzegana wyłącznie jako pieniądz, lecz powinna ona przyczyniać się do „rozwoju twórczych zdolności w człowieku” lub rozwój taki wspierać ${ }^{50}$. Takie spojrzenie na sprawę powoduje, że w centrum zainteresowania postawiona zostaje twórczość człowieka (Schaffen). Każdy, kto pracuje, jest twórcą. W odniesieniu do własności, twórczość jest z jednej strony przez nią wspierana, $z$ drugiej zaś prowadzi do jej wytworzenia. Dla W. Schappa twórczość stanowi ponadto istotną część świata wartości. W swoich rozważaniach na temat własności, twórczości i wartości autor dochodzi do

48 Por. W. Schapp, In Geschichten verstrickt. Zum Sein von Mensch und Ding [1953], Frankfurt a. M. 1985, s. 198.

49 W. Schapp, Zur Metaphysik..., dz. cyt., s. 71.

50 Na temat tych i następnych rozważań dotyczących własności por. tamże, s. 67n. 
centralnej myśli: własność prywatna ma tylko wtedy prawdziwy sens, jeśli mężczyzna jest ojcem i może pozostawić wytworzoną przez siebie własność swym dzieciom. W ten sposób własność prywatna wydaje się znajdować uzasadnienie w ojcostwie, a sięgając jeszcze głębiej - ojcostwo jest wszakże tworem macierzyństwa - w samym macierzyństwie.

Naszkicowaną powyżej relację pomiędzy własnością a ojcostwem należy uzupełnić o rzecz następującą. Według W. Schappa macierzyństwo jest zasadniczym celem życiowym kobiet, podczas gdy ojcostwo nie jest z reguły celem życia mężczyzny ${ }^{51}$. Autor ostrożnie („być może”) zauważa, że mężczyzna odnajduje swoje największe szczęście w sferze zawodowej, wskazując jednakże na znikomość takiego szczęścia w porównaniu ze szczęściem będącym udziałem matki ${ }^{52}$. Obszary życia związane z pracą, zawodem i własnością pozostają zatem domeną ojca. To ojciec tworzy własność, jednakże ta nabiera właściwego znaczenia dopiero w rodzinie. W tym sensie rodzina jest dla ojca czymś niezwykle istotnym. Z kolei mężczyzna jest potrzebny rodzinie, ponieważ zabezpiecza jej materialny byt i dzięki temu rodzina może wypełniać swoją funkcję wychowawczą. Własność prywatna jest więc niezbędnym warunkiem istnienia rodziny w jej zachodnim kształcie. Z tego też względu owa własność wydaje się być niezwykle istotnym elementem filozofii rodziny w rozumieniu W. Schappa, filozofii, która - zgodnie z interpretacją Jana Schappa - pojawia się w miejsce filozofii państwa.

Na zakończenie rozważań dotyczących rodziny i wychowania warto raz jeszcze wskazać na centralne pojęcie traktatu W. Schappa: pojęcie miłości. Pojęcie to, rozpatrywane czysto intelektualnie, może wydawać się czymś ogólnym i abstrakcyjnym. W. Schapp konkretyzuje je w ten sposób, że w swym traktacie łączy je nierozerwalnie z macierzyństwem. Słowo „miłość” jest używane tutaj konkretnie w sensie miłości macierzyńskiej. Zabieg konkretyzacji pojęcia miłości jest o tyle szczęśliwy, że $\mathrm{w}$ ten sposób przesłanie traktatu staje się bardziej czytelne. Albowiem

51 Por. tamże, s. 51n. Autor mówi o „śmiesznym ojcostwie” w przypadku mężczyzn całkowicie zatracających się w byciu ojcem.

52 Por. tamże, s. 53. 
czysto rozumowe spekulacje na temat miłości są od samego początku mało przekonujące. Jako słowo czy też pojęcie, miłość jest zaledwie elementem języka; autorowi chodzi jednak nie o język, lecz o rzeczywistość, i to o taką, którą trudno wyrazić słowami i do której nowożytna nauka, ze swoimi pomiarami, statystykami i mikroskopami, nie ma de facto żadnego dostępu. Wychowanie bez miłości utraciłoby w jednej chwili cały swój sens; oznaczałoby bowiem przygotowanie człowieka nie do życia, lecz do roli robota spełniającego określone funkcje techniczne. Mówiąc tutaj o sensie, chciałbym wskazać na to, że miłość jest nie tylko fundamentem wychowania, lecz że jest ona również jego ostatecznym celem. Jest to notabene przekonanie filozofii co najmniej od czasów Platona, a ostatecznie ugruntowane w chrześcijaństwie.

\section{Problemy. Duchowa ojczyzna myśli Wilhelma Schappa}

Traktat Metafizyka macierzyństwa W. Schappa jest wyrazem wolności duchowej autora, a zarazem nawiązuje niezwykle energicznie do rzeczywistości zastanej: do tradycji i religii chrześcijańskiej. Dlatego też wolność z jednej strony, a tradycja i religia z drugiej są jego istotnymi elementami ${ }^{53}$. Z tym związany jest jednak następujący paradoks: elementy wolnościowe myśli W. Schappa mogą być poddane krytyce ze strony pewnych odmian filozofii chrześcijańskiej, natomiast elementy tradycyjno-religijne - ze strony współczesnej myśli wolnościowej. W pierwszym przypadku mielibyśmy do czynienia ze sporem pomiędzy różnymi metafizykami, w drugim - pomiędzy metafizyką a liberalizmem.

Jeśli chodzi o krytykę z pozycji myśli chrześcijańskiej, to należy zwrócić uwagę przede wszystkim na filozofię realistyczną, wywodzącą się od Arystotelesa i św. Tomasza z Akwinu, a mającą swych zwolenników przede wszystkim w Kościele katolickim ${ }^{54}$. Filozofia owa podkreśla swój

53 Problemem koegzystencji indywidualnej wolności i rzeczywistości zastanej zajmował się między innymi Teodor Litt. Por. T. Litt, Individuum und Gemeinschaft. Grundfragen der sozialen Theorie und Ethik, Leipzig-Berlin 1919.

${ }^{54}$ W Polsce filozofia realistyczna uprawiana jest przede wszystkim na Katolickim Uniwersytecie Lubelskim. 
realistyczny charakter, tzn. fakt, że zajmuje się ona bytem realnie istniejącym, zarówno fizycznym, jak i metafizycznym. Jej metodą jest logiczne myślenie oraz systematyczność wywodu; w ten sposób chce ona podkreślić swój naukowy charakter. Z pozycji tej filozofii można by zadać W. Schappowi dwa zasadnicze pytania; pierwsze dotyczy metody, drugie - treści. Po pierwsze, można zapytać, czy możliwe jest dojście do zadowalających rezultatów, jeśli zamiast systematycznego, logicznego wywodu obiera się intuicję jako metodę. Po drugie, można by również zapytać, czy nie mamy tutaj do czynienia $\mathrm{z}$ sytuacją, w której transcendencja, mimo pewnych pozornych zabiegów, została jednak w gruncie rzeczy zastąpiona immanencją. Może bowiem powstać wrażenie, że W. Schapp, przypisując macierzyństwu niemalże boskie cechy, redukuje całą metafizykę do macierzyństwa. Mówi on, co prawda, o metafizyce macierzyństwa, lecz metafizyka ta wydaje się mieć ziemski, immanentny charakter. O przesunięciu zainteresowania autora $z$ transcendencji na immanencję świadczyć może też jego stwierdzenie, że istota myśli chrześcijańskiej wyrażona została nie w Niedzieli Wielkanocnej, lecz w Wielkim Piątku, tzn. w śmierci, i że myśl chrześcijańska byłaby, być może, jeszcze potężniejsza wówczas, gdyby nie doszło do Zmartwychwstania ${ }^{55}$. O przesunięciu tym świadczy również i to, że W. Schapp mówi o problemie nieśmiertelności duszy jedynie w kontekście rodziców będących nieśmiertelnymi poprzez swoje dzieci. Takie i inne pytania będą się więc nasuwały po uwzględnieniu realistycznej filozofii chrześcijańskiej; w tym miejscu chodzi jedynie o ich zasygnalizowanie, a nie o dokładniejsze zbadanie.

Krytyki można się jednak spodziewać przede wszystkim ze strony współczesnej myśli wolnościowej. Jeśli problem realizmu jest przedmiotem badań wąskiej grupy filozofów, to pojęcie wolności ma fundamentalne znaczenie w życiu każdego współczesnego człowieka. Jednocześnie pojęcie wolności nie jest jakimś nowym wynalazkiem czasów współczesnych: w swym filozoficzno-prawnym traktacie Freiheit, Moral und Recht Jan Schapp wykazał niezwykle jasno, że współczesne pojęcia wolności zostały wypracowane w filozofii Oświecenia, a ta z kolei czerpała swe inspiracje 
z myśli chrześcijańskiej ${ }^{56}$. Nie wdając się tutaj w rozważania na temat różnych pojęć wolności i ich źródeł - jest to temat na osobną dyskusję - należy zauważyć, że dzisiaj wolność jest często pojmowana jako czynienie tego, co się chce. Mówi się często o tak zwanej samorealizacji.

W przypadku wolności rozumianej jako czynienie tego, co się chce, nie są istotne pobudki działania, lecz raczej sam fakt decydowania. Człowiek może działać pod wpływem Bożych przykazań, pod wpływem obowiązku w sensie filozofii Kanta, pod wpływem idei nadczłowieka Nietzschego, czy też powodowany jakimikolwiek innymi pobudkami. Istota wolności będzie polegać na tym, że to właśnie on decyduje. Tak rozumiana wolność nie jest podporządkowana jakimś innym wartościom, na przykład jakiemuś obiektywnemu dobru, lecz sama jest wartością najwyższą.

Możliwa krytyka ze strony współczesnego stanowiska wolnościowego byłaby zatem łatwa do przewidzenia. Taka krytyka wskazałaby przede wszystkim na fakt, że w traktacie W. Schappa najwyższą wartością nie jest wolność w naszkicowanym tu rozumieniu, lecz macierzyństwo. Jedną z głównych myśli Metafizyki macierzyństwa jest przecież to, że mężczyzna i kobieta są istotowo różni, a w związku z tym również ich role społeczne muszą być różne. Takie stanowisko byłoby nie do utrzymania, jeśli przyjęlibyśmy, że subiektywna wolność jednostki jest wartością najwyższą. Wtedy należałoby każdemu pozostawić wybór i mogłoby się okazać, że dla niektórych kobiet, być może nawet dla większości, najwyższą wartością byłoby nie macierzyństwo, lecz coś innego, na przykład praca zawodowa. W. Schapp nie zajmuje się jednak w swej Metafizyce macierzyństwa kwestiami, których tematem byłoby urzeczywistnienie subiektywnych pragnień ludzkich. Jedynie na marginesie zwraca on uwagę na problem dekadencji i czyni dość sceptyczną uwagę na temat feminizmu ${ }^{57}$.

Na problem konfliktu pomiędzy wolnością a metafizyką macierzyństwa można spojrzeć również z innej strony. Można mianowicie potraktować traktat W. Schappa jako jeden z wielu możliwych głosów w dyskusji. Takie podejście byłoby zupełnie zgodne $\mathrm{z}$ duchem liberalizmu. 
Jeśli postrzega się wolność jako wartość najwyższą, to trzeba też umieć przyznać wolność innym. Chodzi tu zatem o wolność przekonań i związaną z nią wolność wypowiedzi. Tymczasem współczesny liberalizm zamienia się nierzadko w swoje przeciwieństwo, nie tolerując w dyskusji pewnych subiektywnych przekonań; staje się on wtedy czymś, przeciwko czemu sam niegdyś występował: dogmatyzmem. Na ten paradoks współczesności zwrócił uwagę niemiecki filozof i teoretyk mediów, Norbert Bolz ${ }^{58}$.

Duchową ojczyzną Wilhelma Schappa wydaje się być świat chrześcijaństwa, dlatego też problematyka rodziny i wychowania nabiera swego ostatecznego sensu dopiero w tym świecie. W zakończeniu rozważań nad Metafizyka macierzyństwa ten właśnie aspekt chciałbym szczególnie podkreślić. Związki pomiędzy chrześcijaństwem a rodziną są tematem wielu fragmentów dzieła, przede wszystkim trzeciej księgi traktatu: Związki zachodzace pomiędzy miłością Boga a miłością macierzyńską. $\mathrm{O}$ związkach tych jest również mowa w ostatnim rozdziale książki In Geschichten verstrickt. Zum Sein von Mensch und Ding ${ }^{59}$. W rozdziale tym autor zwraca uwagę, że do wspólnoty, którą moglibyśmy określić mianem „my” w najgłębszym sensie tego słowa, prowadzą zasadniczo dwie drogi. Z jednej strony drogą do takiej wspólnoty jest inna wspólnota: wspólnota matki i dziecka; z drugiej zaś strony drogą taką może być też religia chrześcijańska. Ostatecznie obydwie drogi wydają się być w gruncie rzeczy jednym i tym samym, ponieważ W. Schapp interpretuje religię chrześcijańską jako odbicie relacji matka - dziecko. Autor postrzega chrześcijańską historię świata jako tę spośród innych zastanych historii, która w naszym kręgu kulturowym najbardziej nadaje się do utworzenia braterskiej wspólnoty, obejmującej wszystkich ludzi. W. Schapp odrzuca jednocześnie możliwość doprowadzenia do braterstwa ludzi jedynie przy pomocy rozumu i nauki. Ani rozum, ani nauka nie są w stanie nadać życiu sensu, ponieważ czerpią one swe siły ostatecznie z chrześcijańskiej historii świata; same z siebie pozostają bezsilne.

58 Por. N. Bolz, Die ungeliebte Freiheit, München 2010, tam zwłaszcza s. 82n.

59 Por. W. Schapp, In Geschichten..., dz. cyt., s. 190n. 
Jeśli przyjąć, że braterstwo to wielki ideał wychowawczy, to widać zatem jasno, że ideał ten może być urzeczywistniony jedynie poprzez miłość, której przekazicielami są rodzina i religia, a nie poprzez rozum czy też naukę. W tym punkcie myśl Wilhelma Schappa jest całkowicie zgodna z poglądami przedstawicieli Kościołów chrześcijańskich ${ }^{60}$. Myśl o prymacie religii nad rozumem i nauką pojawia się również u Dostojewskiego; jest to jeden $\mathrm{z}$ centralnych motywów jego twórczości ${ }^{61}$. Również rodzina jest postrzegana przez niego jako wielkie dobro: $\mathrm{w}$ przytoczonym na początku tej pracy fragmencie powieści Bracia Karamazow jest mowa o domu rodzinnym i o tym, że „piękne, święte wspomnienie, zachowane z dzieciństwa, jest zarazem najlepszym wychowaniem". Słowa te są wyrazem szacunku dla rodziny i jej fundamentalnej roli wychowawczej. Wskazują one również na szersze tło, na którym należy rozpatrywać rodzinę - na chrześcijaństwo. Wynika to nie tylko z użycia sformułowania „święte wspomnienie”, lecz również z kontekstu sytuacyjnego. Mamy tutaj mianowicie do czynienia z mową wygłoszoną przez osobę duchowną przy kamieniu nagrobnym jednego $\mathrm{z}$ bohaterów powieści.

${ }^{60}$ W encyklice Caritas in veritate możemy przeczytać: „Rozum sam z siebie potrafi pojąć równość między ludźmi i ustanowić obywatelskie współżycie między nimi, ale nie jest zdolny ustanowić braterstwa“. Por. Benedykt XVI, Encyklika Caritas in veritate, Kraków 2009, s. 34 (\$19).

${ }_{61}$ Por. F. Dostojewski, Dziennik..., dz. cyt., s. 343n. 